\title{
$\mathrm{Al} /$ サファイヤ常温接合体の界面欠陥成長に 関する破壊力学的考察：はく離試験および 有限要素法による解析
}

\author{
東京大学先端科学技術研究センター \\ J. Japan Inst. Metals, Vol. 64 , No. 6 (2000), pp. 444-450 \\ (C) 2000 The Japan Institute of Metals
}

朴永朝* 榎学須賀唯知岸輝雄

\section{Fracture Mechanical Approach to the Growth of Interfacial Defects in Al/Sapphire Joint Fabricated by SAB: Tearing-Off Test and Analysis by Finite Element Method}

Young Jo Park ${ }^{1}$, Manabu Enoki, Tadatomo Suga and Teruo Kishi

Research Center for Advanced Science and Technology, The University of Tokyo, Tokyo 153-8904

\begin{abstract}
Bonded area is largely affected by the surface morphology and mechanical properties of materials, because the room temperature bonding process is carried out under a low temperature and pressure for a short time. Accordingly, interfacial defects cause unavoidable problems in many cases. For an application of this technology, it is important to elucidate the effect of interfacial defects on fracture behavior. Fracture mechanism and criterion for the growth of interfacial defects were investigated using the Al/Sapphire joint known for easy control of bondability. The results clearly showed that the growth of an interfacial defect was the dominant factor for the crack propagation. A critical stress intensity factor for the growth of interfacial defects was estimated by the analysis of FEM calculation and experimental observation.
\end{abstract}

(Received December 3, 1999; Accepted April 24, 2000)

Keywords: interfacial defect, fracture mechanism, fracture criterion, room temperature bonding

\section{1. 緒言}

従来，金属，半導体，七ラミックスなぞの直接接合は，多 くの場合加熱を行らことで接合材料間に拡散や反応を生じさ せている．従って熱ひずみや熱応力の発生 ${ }^{1)}$ ，脆い反応層の 形成 ${ }^{2)}$ ，接合可能な材料・デバイスの制約といった問題が指 摘されてきた。それに対して，表面活性化常温接合法(Surface Activated Room Temperature Bonding: SAB) は, 被 接合材の表面をイオン衝撃またはラジカルビーム処理などの 物理的手法を用い，超高真空中で清浄かつ活性な表面を作 製，コントロールし，それらを相互接触させることによって 低エネルギーでの接合を実現する新技術として注目を浴びて いる3 。このよらな魅力的かつ画期的な新しい接合法につい て，その原理から接合強度といった実験データまで，様々な 研究結果が報告されている。

しかしながら，今までの研究は主に，結合原理や接合強度 に関する接合条件の影響などの解明を中心として行われたた め，破壊についてはまだ十分な知見が得られていない，真空 中での凝着現象の理解を目的として行われて来た，50年代 からの摩擦係数をたは付着係数の測定試験と4), 近年になっ

* 東京大学大学院生 (Graduate Student, Tokyo University)
てょうやく接合体の接合強度程度が報告されている5゙，常温 接合のプロセスに物いて接合面積率は被接合体の表面形状, 力学特性などの物理的な因子に大きく依存するため6), 多く の場合界面欠陷(未接合部)は避けられないことになる。その ため破壊挙動に関する界面欠陷の影響を明確にすることが， 常温接合体の実用化を目指す上で重要な課題になっている. また，金属/セラミックスのような異種材接合体の場合は弾 性係数の差に起因する混合モード解析が必要とされる1,7-10). しかし，異種材界面き裂の混合モード応力拡大係数を簡易的 に評価寸る方法がないため, 有限要素法などの数值解析手法 を用いる必要がある。

そこで，本研究では他の系に比べて常温接合性に優れた $\mathrm{A} 1 /$ サファイヤからなる接合体を対象として, 供試材の力学 特性も含めた接合条件を調節し, 界面欠陥構造を制御した接 合体のはく離試験を行い, 有限要素法による解析と実験結果 との比較を行い，常温接合体の破壊機構执よび破壊クライテ リオンの導出を試みた.

\section{2. 常温接合体の作製およびはく離試験}

\section{1 常温接合体の作製}

供試材としてc一面研磨されたサファイヤと機械研磨およ び電解研磨後焼鈍を施した多結晶 $\mathrm{Al}$ を用いた．Alの純度は 
99.5\%,99.999\%であり，以下ではそれどれ Al 2nine， A1 5nine と表記する. 両材を超高真空中で冷陰極型高速原 子源 (Fast Atom Beam)照射に上って表面を清浄化し，表面 の再污染が生じない条件を保って厈力を加光接合体を作製し た。接合王力は Al 5nineの降伏応力である $30 \mathrm{MPa}$ より低 い20 MPa と，ょり高い $40 \mathrm{MPa}$ のつにした. $\mathrm{Al}$ 贯材の 純度と接合圧力との組み合わせによって接合面積率を変えた 試験片を作製して，界面欠陌構造の破壊挙動への影響を調べ た．界面欠陷の大きさと架間的分布は透明なサファイヤ側か ら共焦点型レーザー顕微鏡 (CLSM)を用いて直接観察を行っ て測定した。詳細な作製プロセス，接合装置叔よび接合界面 の観察結果は前報6)に報告した通りである。

\section{2 はく離試験}

試験片は T字型で $5 \mathrm{~mm} \times 5 \mathrm{~mm}$ の接合面積を有する。き 裂進展を容易にさせる目的で厚さ $1 \mu \mathrm{m} の \mathrm{Al}$ フォイルを接 合体の界面端に挟んで予き裂を設けた。はく離試験は接合体 のサファイヤ側を固定し，Al 側を一定速度 $(0.1 \mathrm{~mm} / \mathrm{min}) て ゙$ 引張り，き裂を進展させる方法で行った(Fig. 1)。この際き 裂進展過程をサファイヤ側からのビデオマイクロスコープで 収録し，き裂進展荷重祅よび界面欠陌の成長領域の長さを測 定した。また，き裂進展の途中に除荷した試験片の主き裂抏 よび界面欠陥の成長様子と破壊後破断面の観察はそれぞれ共 焦点型レーザー顕微鏡 (CLSM) と走査型電子影微鏡(SEM) を用いて行った。

\section{3. 有限要素法による界面欠陥の応力特異性の計算}

供試材として用いた $\mathrm{Al}$ は降伏応力が低く弾塑性变形を示 す. そのため界面久陷部の応力状態は汎用構造解析プログラ ムを用いた数值シミュレーションによって求めた．実験で測 定した破壊荷重での界面欠陥の応力拡大係数の導出は次の二 つの方法でそれぞれ求め，試験での観察と比較することによ ってその妥当性の検討を試みた。亦ず，方法Ｉとしては有限 要素のメッシュに界面欠陷を導入しない条件で，主き裂によ る界面部の応力場 $\left(\sigma_{1}\right.$ と $\left.\tau_{\mathrm{i}}\right)$ を計算した。 この応力場を界面欠 陥の境界条件として用い，次式によって界面欠陷の応力拡大 係数 $K=\left(K_{1}^{2}+K_{2}^{2}\right)^{1 / 2}$ を求めた ${ }^{11)}$.

$$
\begin{aligned}
K_{1}= & \frac{\sqrt{a}}{\cosh \pi \varepsilon}\left\{\sigma^{i}[\cos (\varepsilon \log 2 a)+2 \varepsilon \sin (\varepsilon \log 2 a)]\right. \\
& \left.+\tau^{i}[\sin (\varepsilon \log 2 a)-2 \varepsilon \cos (\varepsilon \log 2 a)]\right\}
\end{aligned}
$$

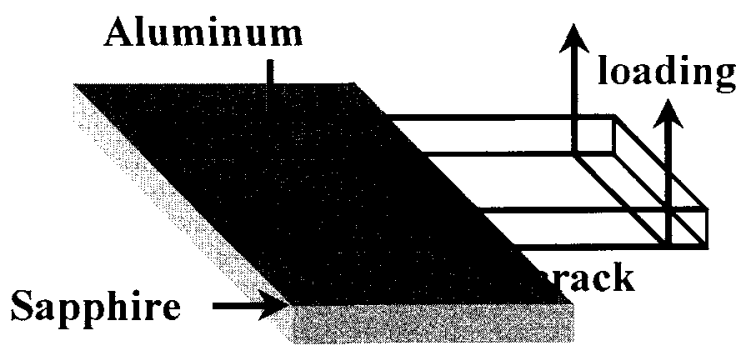

Fig. 1 Schematic illustration of tearing-off test.

$$
\begin{aligned}
K_{2}= & \frac{\sqrt{a}}{\cosh \pi \varepsilon}\left\{\tau^{i}[\cos (\varepsilon \log 2 a)+2 \varepsilon \sin (\varepsilon \log 2 a)]\right. \\
& \left.-\sigma^{i}[\sin (\varepsilon \log 2 a)-2 \varepsilon \cos (\varepsilon \log 2 a)]\right\}
\end{aligned}
$$

ここで, $a$ は界面欠宿の半径, $\varepsilon$ は異材間の接合体の適合性 を特性付けるD Dunders パラメータ $\beta$ で表され， $\varepsilon=(1 / 2 \pi)$ $\ln ((1-\beta) /(1+\beta))$ のバイメタル定数である.

次に，方法川のシミュレーション方法は，主き裂からの距 離 $\left(d_{\mathrm{c}}\right)$ に大ささ $2 a$ の界面欠陥があるとして計算を行い，そ の応力特異性を式 (2)を用いて近似して界面欠陥の応力搪 大係数を求めた ${ }^{10)}$.

$$
\begin{aligned}
& K_{1}=\lim _{r \rightarrow 0} \sqrt{2 \pi r}(\sigma \cos Q+\tau \sin Q) \\
& K_{2}=\lim _{r \rightarrow 0} \sqrt{2 \pi r}(\tau \cos Q-\sigma \sin Q)
\end{aligned}
$$

ただし， $Q=\varepsilon \ln (r / 2 a)$ である.同時に仮想き裂進展法によ る界面欠陥成長に伴う J 積分を計算し ${ }^{12)}$ ，前述した方法で 求めた值との比較を行った。この際界面欠陷の塑性鏰化を避 ける手段として，接合界面の $\mathrm{Al}$ 側にはFig. 2 に示した模式 図のような厚さ $h$ SSVモデルによる弾性層を導入し た 13-15). 要素構成としては 2 次元平面ひずみを仮定し, 計 算の便宜上界面欠宿は貫通き裂とした。メッシュは全て 4 節点平面ひずみ要素とし, 要素の数は最大で5400個, 要素 の一番短い長さは界面欠陌の大きさの1000分の1であった。 収束性を確かめるため, 粗いメッシュから要素の数を増やし ながら計算を繰り返し行った。計算の入力データとして用い た接合体の形状寸法执よび力学特性は Table 1 に示した。

\section{4. 結果および考察}

\section{1 き裂進展機構}

接合体の界面観察から，不純物の多い $\mathrm{A} 12$ 2nine の接合体 は $\mathrm{Al}$ 母材に多く存在する第 2 相の電解研磨エッチピットに よって，Al 5nine の接合体に比べて界面欠陷の大きさは小 さく，頻度は大きい分布を示した。はく離試験を行った結

\begin{tabular}{|c|c|}
\hline $\mathrm{Al}$ & Sapphire \\
\hline $\begin{array}{lr}\text { Polycrystal } & 99.5 \%, 99.999 \% \\
\text { Specimen size } & 5 \mathrm{~mm} \times 7 \mathrm{~mm} \times 3 \mathrm{~mm} \\
\text { Yield stress } & 30 \mathrm{MPa} \\
\text { Work-hardening }\left(\sigma=k \varepsilon^{n}\right) & \\
\quad k=179 \mathrm{MPa} \\
\quad n=0.4\end{array}$ & $\begin{array}{l}\text { Single crystal } \quad(c \text {-plane }) \\
\text { Specimen size } 5 \mathrm{~mm} \times 10 \mathrm{~mm} \times 2 \mathrm{~mm} \\
\text { Treated as elastic } \\
\quad E=420 \mathrm{GPa} \\
\quad \nu=0.2\end{array}$ \\
\hline
\end{tabular}
果, $90 \%$ 以上の接合面積率を得た $\mathrm{A} 15$ nine $の 40 \mathrm{MPa}$ 接合 体ではさ裂は進展せず， $\mathrm{Al}$ 自体の変形あるいはサフォイヤ

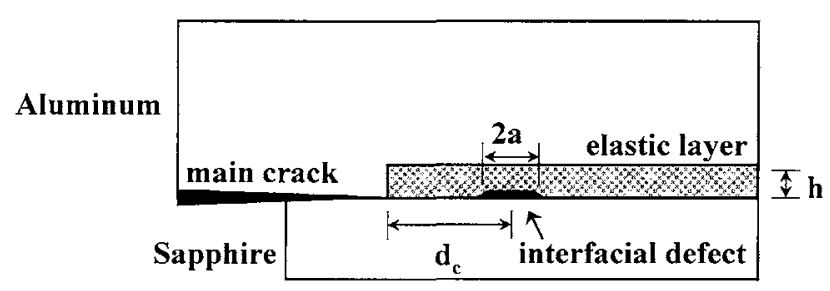

Fig. 2 Schematic illustration of SSV Model.

Table 1 Properties and size of materials. 
側の破壊を示した。また， $\mathrm{Al}$ 2nine の $20 \mathrm{MPa}$ 接合体は試 験および解析に十分な接合は得られなかった。をここで，以下 にき裂進展挙動が明確にとらえられた $\mathrm{Al}$ 2nine の $40 \mathrm{MPa}$ 接合体 (以下 2 nine-40 MPa 材) とA1 5 nine $の 20 \mathrm{MPa}$ 接合 体 (以下 5 nine-20 MPa 村) の試験結果を述べる.

き裂進展の際主き裂和よび主き裂の前方に存在する界面欠 陌の挙動を詳しく調べるため，き裂進展直後除荷した試験片 のき裂先端部を共焦点型レーザー顕微鏡によって観察を行っ た(Fig. 3)．主き裂とき裂進展方向を図火示した。両接合体 とも主き裂前方の領域で界面はく離による界面欠陥の成長 . 合体が観察された。Fig. 3(b)の 5nine-20 MPa 材に扣いて 図示した部分は，界面はく離によって島状火孤立したまだ接 合されている部分を示している，界面欠陷は成長に伴って大 きく鈍化することが，深さ方向の波紋状コントラスト拉よび SEM 観察で分かった。このような部分では荷重増加によっ て $\mathrm{Al}$ 自体の延性破壊が推定される。一方, Fig. 3(a)の 2nine-40 MPa 材では界面欠陷の顕著な鈍化は見られなかっ た. 本論文では，界面欠陥成長領域の長さを臨界距離と定義 し，その值はき裂進展開始の際 2nine-40 MPa 材と5nine$20 \mathrm{MPa}$ 材に括いてそれぞれ約 $200 \mu \mathrm{m}$ と $330 \mu \mathrm{m}$ 程度であ った. Fig. 4 火破断面のSEM写真を示した. Fig. 4(a)は 2nine-40 MPa 材の $\mathrm{Al}$ 側であり，これに対するサファイヤ
側では $\mathrm{Al}$ の接痕が見つからなかったことから界面はく離の みによってき裂が進んだことが分かった。一方，5nine-20 $\mathrm{MPa}$ 材の場合はサファイヤ側で $\mathrm{Al}$ の接痕が観察され，界面 久陷の成長および残った $\mathrm{Al}$ の破壊によってき裂が進むこと が明らかになった(Fig. 4(b))。すなわち，延性金属/七ラミ ックス接合体でよく知られているように, 主き裂先端は鈍化 しているため主き裂自体の進展は不可能である15)。代わり に，界面欠陷加成長し，合体することによって見かけ上主き 裂が進展した。また，2nine-40 MPa 材の場合は矢印で表示 される直径 $10 \mu \mathrm{m}$ 程度の界面欠宿は成長しないことが観察 され，これを成長が生じない臨界欠陷大きさとした。しかし ながら，5nine-20 MPa 材の場合は破断面から臨界欠陥大き さの区別はできなかった. 以上のように Al 2nine 接合体と Al 5nine 接合体で異なる破壊機構は, AE 原波形解析による 微視破壊の非破壊評価によっても確認でさた16).

\section{2 主き裂の応力場による界面欠宿成長のクライテリオン}

主き裂の前方に存在する界面欠陌は，外部荷重を加えたと き主き裂の応力場《よって与えられる応力集中を受ける。特 に, 本研究のような異材界面上のき裂は負荷様式によらず弾 性係数の差に起因して必ず混合モード破壊を示すことが知ら れている，そこで今節と次節に执いては前節の観察を通して
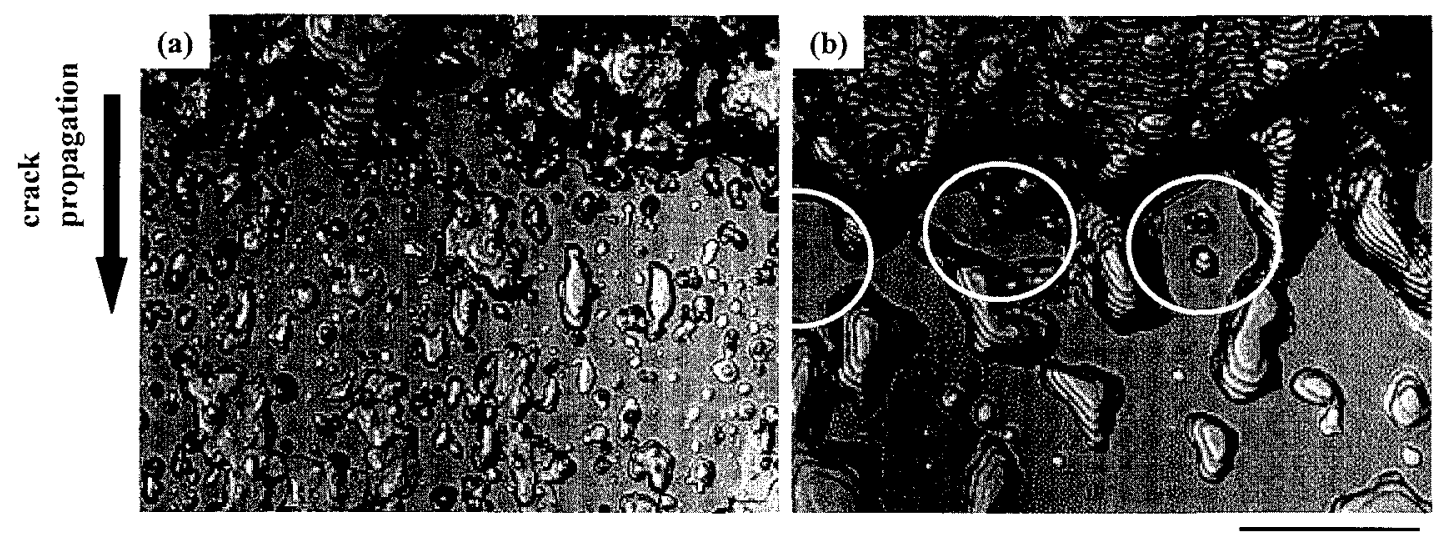

$100 \mu \mathrm{m}$

Fig. 3 In-Situ observation of crack propagation through transparent sapphire (CSLM $\times 700)$.

(a) Al 2nine-bonded at $40 \mathrm{MPa}$, (b) Al 5nine-bonded at $20 \mathrm{MPa}$.
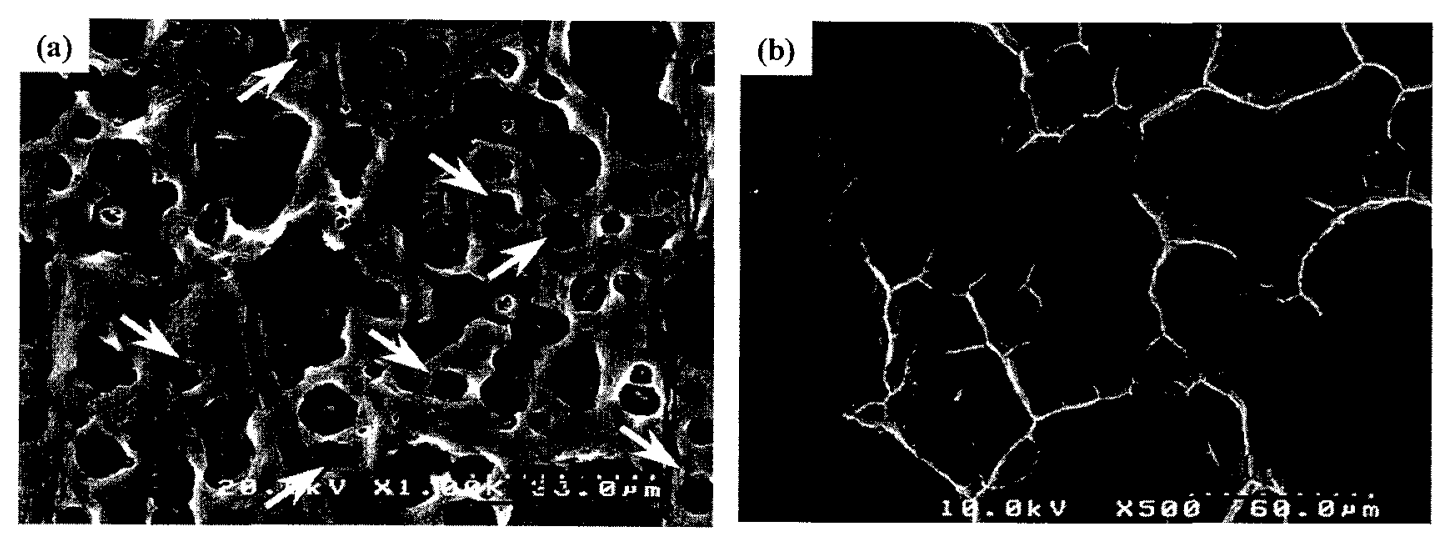

Fig. 4 SEM micrographs of fracture surface.

(a) Al side of Al 2nine-bonded at $40 \mathrm{MPa}(\times 1000)$, (b) Sapphire side of Al 5nine-bonded at $20 \mathrm{MPa}(\times 500)$. 
き裂進展挙動を支配することが明らか炕なった，界面欠陷の 混合モード成長クライテリオンを破壊力学的手法で考察を行 った.

まず，界面欠宿がないときの主き裂による応力場を有限要 素法で計算して，主さ裂から任意の距離にある界面欠陥での 応力拡大係数を求めた. Fig. 5 は 2nine-40 MPa 材の臨界距 離 $200 \mu \mathrm{m}$ に位置する貫通型抢よび円盤型界面欠阫の半径と 応力拡大係数の関係をプロットしたものでする，接合界面で 観察される最大欠陷大きさである直径 $30 \mu \mathrm{m}$ の範囲では, 両者が殹济一致する傾向を示すことが分かる．本論文では 2 次元解析を行うため，以下で慣通型界面欠陷を対象とした。

界面欠陥の臨界広力拡大俰数を求めるためには，先法どの 臨界距離, 臨界久陷大きさに加光て最大欠楩大きさのデータ が必要となる．Fig. 6 は界面欠陥の大きさ分布の測定結果で ある. 2nine-40 MPa 材と5nine-20 MPa 材に和いて，最大 欠陥大ささはそれどれ約 $30 \mu \mathrm{m}$ と $100 \mu \mathrm{m}$ 程度と観察され た。界面欠陥成長に関する特性值をTable 2 にまるた。

Fig. 7 には種々の界面久陷の大きさに対する，主き裂先端か らの距離での応力拡大係数を示した。 2nine-40 MPa 材の昜

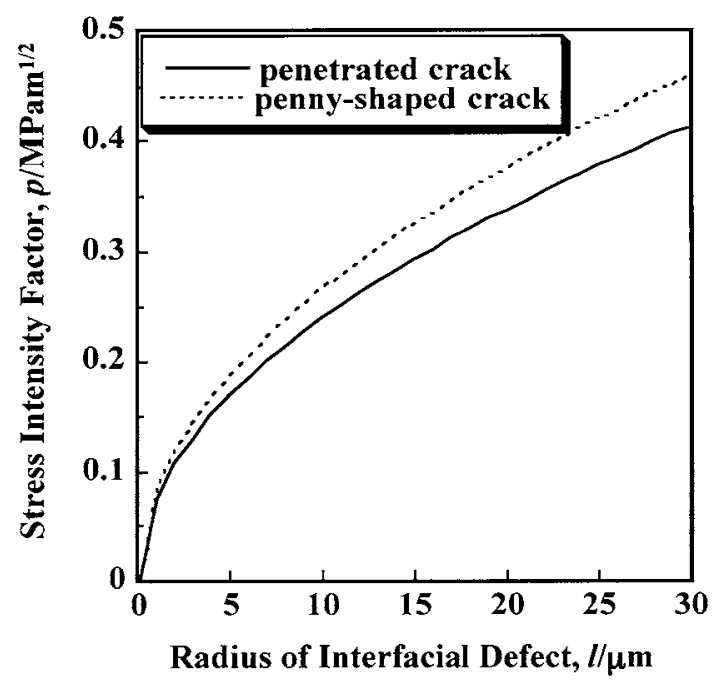

Fig. 5 Stress intensity factor for interfacial defects of $\mathrm{Al}$ 2nine located at the critical distance of $200 \mathrm{~mm}$.

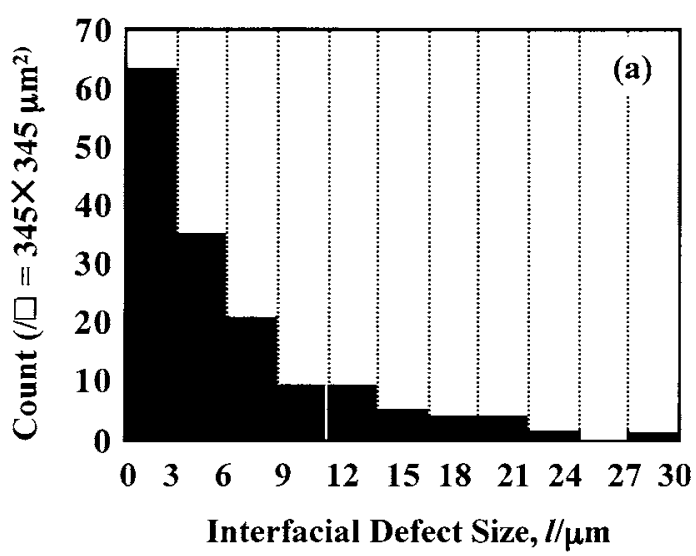

合 (Fig. 7(a))，臨界欠陷大きさである半径 $5 \mu \mathrm{m}$ の界面欠陌 を用いて臨界応力拡大係数は約 $0.3 \mathrm{MPa} \cdot \mathrm{m}^{1 / 2}$ と認められ た。 また，接合まま材の最大欠陷大きさ約 $30 \mu \mathrm{m}$ の欠陥は， こうして求めた臨界応力拡大係数を用いた場合界面欠陷の成 長領域は約 $200 \mu \mathrm{m}$ になって，除荷試験片で実験的に観察さ れた臨界距離と一致した。 5 nine-20 MPa 材の昜合にも，観 察された臨界距離約 $330 \mu \mathrm{m}$ 和よび最大久陷大きさ約 100 $\mu \mathrm{m}$ を用いて 2nine-40 MPa 材と活添等しい臨界応力拡大係 数が得られた(Fig. $7(\mathrm{~b}))$.

一方，接合变季材の界面欠宿の高さは接合前の $\mathrm{A} 1$ の表面 粗さ叔よび接合まま材の界面欠宿観察によって $1 \mu \mathrm{m}$ 以下で あった，成長が止まったところの界面欠陷の高さは約 $5 \mu \mathrm{m}$ 以上であった。一旦成長し始めた界面欠陷が，ある程度の大 きさで成長が止まって未接合部に囲まれた $\mathrm{Al}$ 自体の破壊に 移るのは, 界面欠陥の塑性変形によるき裂の鈍化に伴ら応力 拉大係数の減少のためであると考觉られる。

以上で用いた式 (1) は弾性解析による厳密解であるが， 供試材 $\mathrm{Al}$ は弾塑性変形を有するためそれを適用した場合に は妥当性が問われる。しかしながら，本研究のはく離試験に 执いて破壊荷重での von Mises 条件による降伏領域は, 臨 界距離より小さかったので，式（1）を用いることは十分妥 当であると考觉られる。

\section{3 界面欠宿の応力特異性および $J$ 積分による界面欠陷成 長のクライテリオン}

界面欠陥成長をモデル化して Fig. 2 で示したメッシュを 構成し, 界面欠陷部の応力特異性の計算を試みた。界面欠陷 の要素は臨界距離の位置に最大欠陥大ささで構成された。 SSV モデルの仮定に基ついて, 接合界面に沿う $\mathrm{Al}$ 側の弾性 層は母材 $\mathrm{Al}$ と同じ弾性係数扣よびポアソン比を有するもの とした。このような弾性層の導入は材料に存在する転位の平 均間隔を考慮した計算結果から行われた13)。 また, 延性材 料のき裂先端での塑性鈍化を伴わない応力集中を説明する目 的で行われてきた14,15). 弾性層の厚さ $h$ は $0.1 \sim 1 \mu \mathrm{m}$ 程度 と報告されている。本研究の観察から百き裂の鈍化は観察 されたが，界面欠陌はある大きさまでは成長することが明ら かとなった，予備計算として界面欠陥を入れない条件で，弾

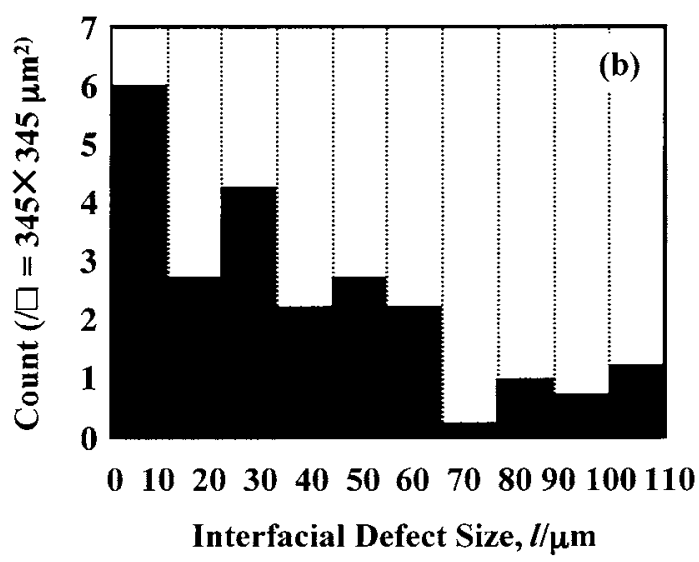

Fig. 6 Distribution of interfacial defect size.

(a) Al 2nine-bonded at $40 \mathrm{MPa}$, (b) Al 5nine-bonded at $20 \mathrm{MPa}$. 
性層の厚さを $1 \mu \mathrm{m}$ と $10 \mu \mathrm{m}$ にしたとさの応力状態を調べ た. その結果，大差のない值が得られたこと拈よび界面欠陥 を導入する際要素構成の便宜上弾性層の厚さを $10 \mu \mathrm{m}$ とし

Table 2 Characteristic values for the determination of critical stress Intensity factor.

\begin{tabular}{lccl} 
& $\begin{array}{c}\text { Al 2nine- } \\
\text { bonded at } \\
40 \mathrm{MPa}\end{array}$ & $\begin{array}{c}\text { Al 5nine- } \\
\text { bonded at } \\
20 \mathrm{MPa}\end{array}$ & Measurement \\
\hline $\begin{array}{l}\text { Critical distance } \\
\text { distance within which the } \\
\text { growth of interfacial defect } \\
\text { was observed }\end{array}$ & $200 \mu \mathrm{m}$ & $330 \mu \mathrm{m}$ & $\begin{array}{l}\text { in-situ specimen } \\
\text { Video-Microscope }\end{array}$ \\
\hline $\begin{array}{l}\text { Critical defect size (radius) } \\
\text { limit size not to grow }\end{array}$ & $5 \mu \mathrm{m}$ & $\begin{array}{l}\text { Fracture surface } \\
\text { SEM }\end{array}$ \\
\hline $\begin{array}{l}\text { Maximum defect size } \\
\text { (radius) }\end{array}$ & $15 \mu \mathrm{m}$ & $50 \mu \mathrm{m}$ & $\begin{array}{l}\text { as-bonded } \\
\text { CSLM }\end{array}$ \\
\hline
\end{tabular}

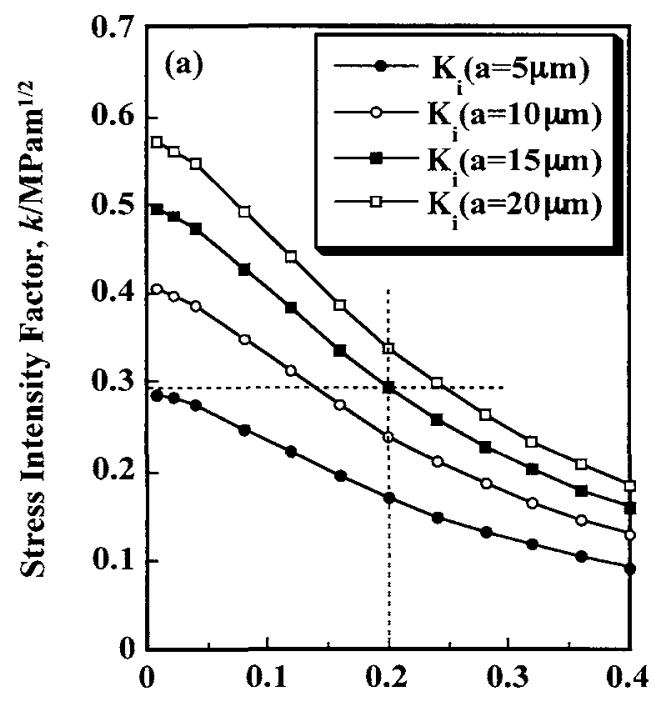

Distance from the Main Crack, $I / \mathrm{mm}$
て計算を行った.

上述の方法で求めた応力場を式 (2) 亿代入し, その極限 值と乙て界面欠陷の応力搪大係数を求めた(Fig. 8). 臨界応 力搪大係数虫両接合体之破壊荷重 $\left(L_{\text {ext }} / L_{\mathrm{f}}=1.0\right)$ で 0.1 $0.2 \mathrm{MPa} \cdot \mathrm{m}^{1 / 2}$ 程度比計算された. Fig. 9 亿は界面欠陥近傍 で行われたJ積分の結果を示した．外部荷重の㙕加に伴いエ ネルギー解放率は高くなる。一方，同じ荷重の場合はある大 きさの界面欠宿のところで最大值を示すことが分かった．同 様な傾向が金属と剛体との接合体を想定した引張試験をモデ ル化した計算で報告されている15)，最大欠陷大ささと破壊 荷重から得られる臨界エネルギー開放率は $1.3 \sim 2.3 \mathrm{~J} / \mathrm{mm}^{2}$ 程度となった。サファイヤ単体の破填エネルギーは $12 \mathrm{~J} /$ $\mathrm{mm}^{2}$ でありこの值より大きいので，界面欠陌の成長は界面 に沿ら経路を持つ界面はく離であることを意味する。また，

Fig. 7 Determination of critical stress intensity factor for the growth of interfacial defect (at $L_{\text {ext }}=L_{\mathrm{f}}$ ) by Method I. (a) Al 2nine-bonded at $40 \mathrm{MPa}$, (b) Al 5 nine-bonded at $20 \mathrm{MPa}$ (where, $L_{\text {ext }}$ : external load, $L_{f}$ : fracture load).

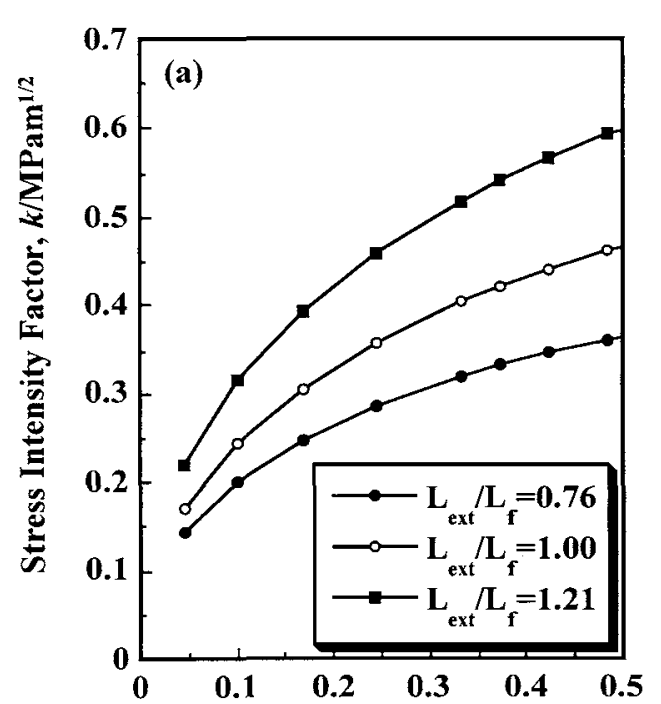

Distance from Interfacial Defect (r/a)

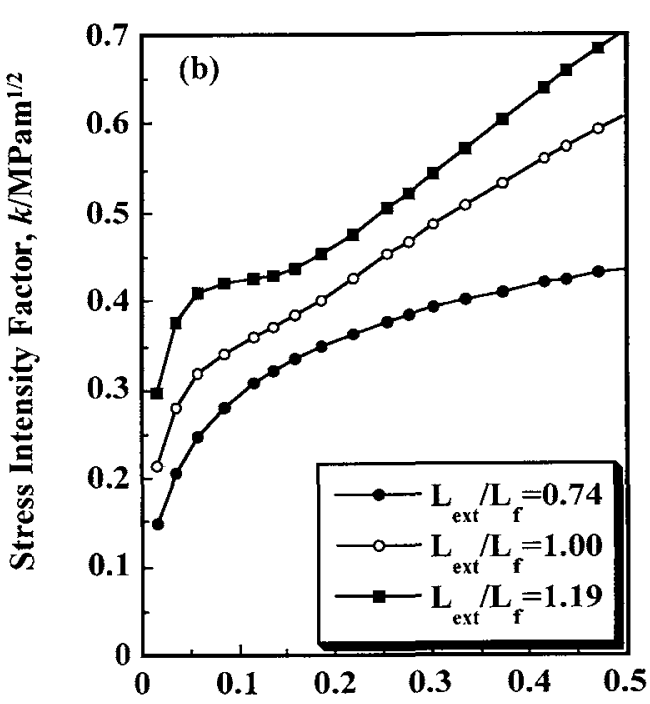

Distance from Interfacial Defect (r/a)

Fig. 8 Derivation of stress intensity factor from the stress distribution near the interfacial defect by Method II. (a) Al 2nine-bonded at $40 \mathrm{MPa}$, (b) Al 5nine-bonded at $20 \mathrm{MPa}$ (where, $L_{\text {ext }}$ : external load, $L_{\mathrm{f}}$ : fracture load). 

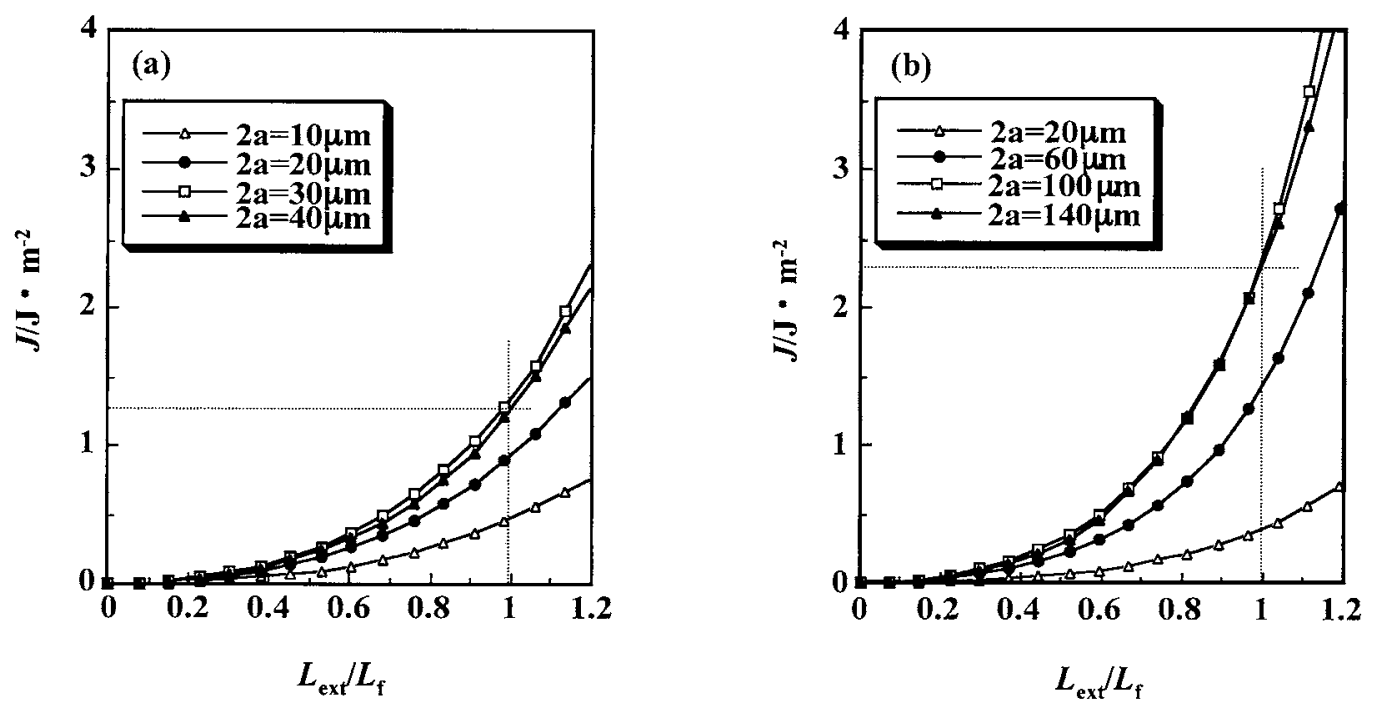

Fig. 9 Calculation of $J$-integral by VCEM (Virtual Crack Extension Method) for interfacial defects located at critical distance. (a) Al 2nine-bonded at $40 \mathrm{MPa}$, (b) Al 5nine-bonded at $20 \mathrm{MPa}$ (where, $L_{\text {ext }}$ : external load, $L_{\mathrm{f}}$ : fracture load).
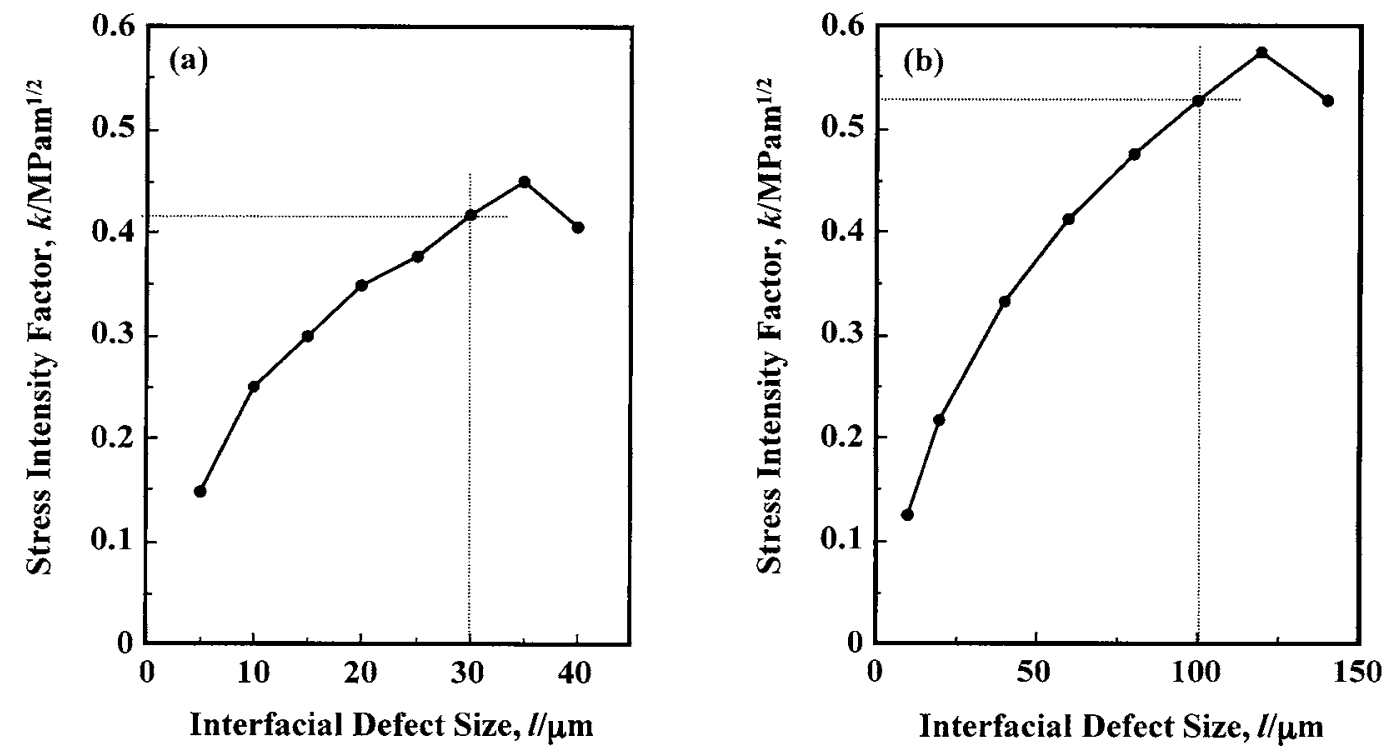

Fig. 10 Conversion of calculated $J$-integral value into stress intensity factor. (a) Al 2nine-bonded at $40 \mathrm{MPa}$, (b) Al 5 nine-bonded at $20 \mathrm{MPa}$.

異材界面の応力桩大䋆数とェネルギー解放率は次式の上うに 関保付けられる17).

$$
G=\frac{1}{16 \cosh ^{2}(\varepsilon \pi)}\left(\frac{\chi_{1}+1}{\mu_{1}}+\frac{\chi_{2}+1}{\mu_{2}}\right)\left(K_{1}^{2}+K_{2}^{2}\right)
$$

Fig. 9 の破壊荷重 $\left(L_{\text {ext }} / L_{\mathrm{f}}=1.0\right)$ でのエネルギ一解放率を式 (3) 亿上って応力拡大係数深算し，その結果を Fig. 10 K

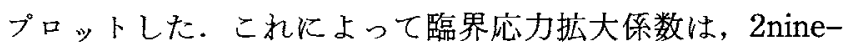
$40 \mathrm{MPa}$ 材 (Fig. 10(a))では最大久陷大きさ $30 \mu \mathrm{m}$ で約 $0.4 \mathrm{MPa} \cdot \mathrm{m}^{1 / 2}, 5$ nine- $20 \mathrm{MPa}$ 材 (Fig. 10(b)) では最大欠陥 大きさの $100 \mu \mathrm{m}$ で約 $0.5 \mathrm{MPa} \cdot \mathrm{m}^{1 / 2}$ と得られた．方法 Iの 界面欠陷を要素構成に入れなかった力法の結果と比べると， 方法Iの界面欠宿の応力特異性から計算した值は小さく $J$ 積 分から換算した値は大きいことが指摘される。これはSSV モデルによる弾性層の外側にある $\mathrm{Al}$ 母材の塑性変形の影響 が原因であると考光られる。また，主き裂と界面欠陥の相互
作用 (interaction)を考虑しない応力法より，その影響を考虑 できるエネルギー法 ( $J$ 積分)の方が有效であると考光られる.

\section{5. 結 論}

接合条件を变化させ，接合面積率拉よび界面欠宿構造を制 御した $\mathrm{Al} /$ サファイヤ常温接合体のはく離試験と $\mathrm{FEM}$ 解析 を行い，以下の知見が得られた。

(1) 2nine-40 MPa 接合体は界面欠陥の成長のみで, 5nine-20 MPa 接合体は界面欠陥の成長特よび Al 母材の延 性破填见上ってき裂蛙進展する。また，90\%以上の接合面 積率を有する 5 nine-40 MPa 接合体の場合にはき裂進展は 起こらなかった。

（2）き裂進展を支配する因子は界面欠陮の成長有無である ことが明らかになった。 
（3）有限要素法以よる数值解析結果と実験観察との比較を 行い, 異材界面に存在する界面欠陥成長クライテリオンを導 出できた。

（4）常温接合の応用分野として有望な表面実装のウェーハ ボンディングのような弾性体の界面破壊に関しては，本研究 で行った解析手法が有効であることが示された。

最後に本研究は日本学術振興会未来開拓学術研究推進事業 (JSPS-RFTF96P00404)の一環として行われたことを記し 謝意を表する。

\section{文献}

1) R. Yuuki and J. Q. Xu: Trans. Jpn. Soc. Mech. Eng., 60(1994), $2544-2552$

2) A. G. Evans and B. J. Dalgleish: Acta metall. mater., 40 (1992), s295-s306.

3) T. Suga, Y. Takahashi, H. Takagi, B. Gibbesch and G. Elssner: Acta metall. mater., 40(1992), S133-S137.

4) S. V. Pepper: J. Appl. Phys., 47 (1976), 801-808.
5) Y. Takahashi, H. Takagi, T. Suga, B. Gibbesch, G. Elssner and Y. Bando: J. Japan Inst. Metals, 9(1991), 1002-1010.

6) Y. J. Park, M. Enoki, T. Suga and T. Kishi: J. Japan Inst. Metals, 63 (1999), 1485-1489.

7) R. Yuuki, J. Q. XU and Y. Mutho: J. Japan Inst. Metals, 60 (1994), 2544-2552.

8) G. E. Beltz and J. S. Wang: Acta metall. mater., 7(1992), 1675-1683.

9) S. T. Raveendra and P. K. Banerjee: Engineering Fracture Mechanics, 40(1991), 89-103.

10）結城良治：界面の力学, 培風館, (1993)

11) G. C. Sih: Handbook Stress Intensity Factors, Institute of Fracture and Solid Mechanics, Lehigh University, (1973).

12) D. M. Parks: Int. J. Fract., 10 (1974), 487-502.

13) Z. Suo, C. F. Shih and A. G. Varias: Acta metall. Mater., 41(1993), 1551-1557.

14) A. G. Varias, Z. Suo and C. F. Shih: J. Mech. Phys. Solids, 39(1991), 963-986.

15) M. Y. He, A. G. Evans and J. W. Hutchinson: Acta mater., 44(1996), 2963-2971.

16) Y. J. Park, M. Enoki, T. Suga and T. Kishi: Proc. 9th International Symposium on Nondestructive Characterization of Materials, ed by R. E. Green, Jr., Sydney in Australia, (1999), pp. 21-26.

17) B. Malyshev and R. Salganik: Int. J. Fract. Mech., 1(1965), 114-119. 